\title{
Study on Time-related Changes in Aerobic Bacterial Pattern of Burn Wound Infection
}

\author{
SK Saha', N Muazzam², SA Begum³, A Chowdhury', MS Islam5, R Parveen ${ }^{6}$
}

\begin{abstract}
A prospective study was carried out in 50 bum patients admitted in Bum unit of Dhaka Medical College Hospital over a period of one year from J anuary 2005 to December 2005 to eval uate time rel ated changes in aerobic bacterial colonization and their sensitivity pattem. Periodic swabs were taken from the bum wound on Day 0, Day 7, Day 14 and Day 21 to see the changing pattern of organisms during hospital stay of patients. In the present study bum injury was highest in the age group 11-20 yrs (34\%). Male to female ratio was 1.38:1. The mean percentage of burn was $35.79 \%$ of total body surface area (TBSA). Fire was the maj or cause of bum (38\%) followed by electric burn (20\%). A mong the 200 samples, single organism was isolated in $71 \%$ samples and mixed organism in $13.5 \%$ and no growth in $14.5 \%$. Among single isolates Pseudomonas aeruginosa was leading (28\%) followed by Escherichia coli (17.5\%), Staphylococcus aureus (16\%), coagulse negative Staphylococcus (4.5\%) and Klebsiella (2\%). Among mixed growth Pseudomonas aeruginosa was still leading (11\%) follow by E. coli $(9.5 \%)$ Staphylococcus ( $5.5 \%)$, Proteus (1\%) and Klebsiella (0.5\%).There were time -related changes in bacterial isolation from burn wound during hospital stay of patients. On admission $42 \%$ of the isolated organisms were Staphylococcus aureus and only $6 \%$ each Pseudomonas aerunginosa and $\mathrm{E}$. coli were isolated. No growth was found in $28 \%$. samples. These findings were gradually changing with time and on day 21 Staphylococcus aureus were only $4 \%$ whereas Pseudomonas aeruginosa were $40 \%$ and $\mathrm{E}$. coli $28 \%$. Antimicrobial sensitivity test showed that pseudomonas aeruginosa was highly resistant to antimicrobial agents. It was most sensitive to Imipenem (98.72\%) followed by Aztreonam (33.44\%), Ceftazidime (38.32\%) and Gentamicin (19.23\%). E. coli was also found most sensitive to Imipenem (98.15\%) followed by Gentamicin (38.95\%), Chloramphenicol (37.1\%), Ciprofloxacin (35.25\%) and ceftraixone (29.70\%). Staphylococcus aureus was $100 \%$ sensitive to Vancomycin followed by Amoxiclav and Oxacillin (53.43\% each), Gentamicin (44.70\%) and Cloxacillin (39.52\%). It is crucial for every bum institution to determine the specific pattern of burn wound microbial colonization, the timerelated changes in dominant flora, and the antimicrobial sensitivity profiles. This would enable early treatment of septic episodes with proper empirical systemic antibiotics without waiting for culture results, thus improving overall infection related morbi dity and mortal ity.
\end{abstract}

1. Dr. Sanjay Kumar Saha DCP, M.Phil (Microbiology), Assistant Professor, Department of Microbiology,FMC, Faridpur.

2. Prof. Naima Muazzam M.Phil (Microbiology), M.Med, Professor of Microbiology, NIPSOM, Dhaka.

3. Dr. Shahin Ara Begum M.Phil(Microbioloy), Assistant Professor, Department of Microbiology, Comilla Medical College, Comilla.

4. Dr. Aktaruzzaman Chowdhury M.Phil(Microbiology), Lecturer, Department of Microbiology, DMC, Dhaka.

5. Dr. Md. Saiful Islam M.Phil(Microbiology), Lecturer, Department of Microbiology, Shahid Sarwarthy Medical college, Dhaka.

6. Dr. Rezina Parveen M.Phil(Microbiology), Lecturer, Homeopathic Medical College, Dhaka.

Address of correspondence

Dr. Sanjay Kumar Saha DCP, M.Phil (Microbiology), Assistant Professor, Department of Microbiology, FMC, Faridpur, Cell: +88-

01711783079, Email:drsanjay1961@gmail.com

\section{Introduction}

Bum injury is a major problem in many areas of the world. It has been estimated that $75 \%$ of all deaths following thermal injuries are related to infection ${ }^{1}$. Bum incidences are very common in our country. Burn is the fifth leading cause of child injury in Bangladesh. About 340 children are fatally bumt each year with almost one child dying each day $^{2}$. But unfortunately specialized burn hospital is available only in Dhaka. The increase rate of burn wound infection and sepsis is due to overcrowding, inadequate sterilization and disinfection practices, gross contamination of environment, lack of isolation facilities, inadequate hand washing and absence of barrier nursing ${ }^{3}$. Burn wound allows microbial penetration and bum eschar provides an excellent culture medium for microorganisms with a significant alteration of immune function. Patients have to stay for long period in the hospital and many intravascular and other devices are put in them Hence they are at greater risk of acquiring hospital-acquired infection. Overcrowding in developing countries increases the risk ${ }^{3}$. The organisms that predominate as causative agents of bum wound infection in any burn treatment facility change over 
time. Gram positive organisms are initially prevalent during hospital stay of patients; then gradually become superceded by gram negative opportunists that appear to have a greater propensity to invade'. For every burn institution there should have separate burn management protocol, as the prevalence and type of organisms may vary from centre to centre $e^{5}$ Infection in burns is not only important in being responsible for death but it is also an important factor in the prolongation of hospitalization time and delay in skin grafting. It is therefore essential for every burn institution to determine its specific pattern of burn wound microbial colonization, timerelated changes in predominant flora and anti microbial sensitivity profiles ${ }^{6}$. This would allow early management of Imminent septic episodes with empirical systemic antibiotic before the results of microbiologic culture becomes available thus improving overall infection related morbidity and mortality ${ }^{6}$. In spite of its importance, time related changes in burn wound microbial flora were not investigated by many burn institutions. In Bangladesh, study on etiology of burn wound infection has been carried out previously where timerelated changes in microbial colonization were not included. In view of the abovediscussion present study was designed.

\section{$M$ aterials and $M$ ethods}

The microbial colonization of wounds was studied weekly from the date of admission to the 21st day of hospitalization. So total number of samples of 50 patients was 200 . On admission, the sampling procedure included collection of swab from clinically deep area of bum wound site prior to any cleansing. Later swabs were taken on occasions of surgical debridement or surgical excision and grafting. In each sampling procedure, the bandages were removed, the remnants of topical antimicrobial agents were scraped away and the wounds were swabbed before washing and applying new topical antimicrobial agents. Swabs were collected by using sterile cotton tipped swabs. Specimens were immediately transferred to sterile test tube. In case of collection of sample from dry surface, swabs were moistened with sterile normal saline. After collection, tubes were plugged properly, labeled and carried promptly to the microbiology laboratory of Dhaka Medical College. Wound swabs obtained from the bum patients were subjected to microbiological anal ysis. The Isolates were identified by standard microbiological techniques and their antibiotic susceptibility was determined by using Stokes disc diffusion technique.

\section{O bjectives:}

1. To perform aerobic culture of four samples from each burn wound case and their sensitivity pattern at a regular interval of seven days.

2. To develop a guideline for empirical treatment on the basis of timerelated changes and antimicrobial sensitivity pattern of aerobic bacteria causing burn wound infection

E thical issues: Written or verbal consent of patient or legal guardian and permission of the respective authority of bum unit were taken.

Inclusion criteria: Patients admitted within 24 hours of bum injury.

Exclusion criteria:

1. Patients admitted after 24 hours of burn injury.
2. Referred from other hospital.

3. Patient with more than $70 \%$ total body surface area bum (TBSAB).

\section{Results}

Among the total isolates single organisms were isolated in $71 \%$ samples, mixed organisms in $13.5 \%$ samples and no growth in $15.5 \%$ samples Among single isolates Pseudomnas aeruginosa was leading (28\%) followed by Escherichia coli (17.5\%), Staphylococcus aureus, (16\%), Coagulase negative Staphylococcus (4.5\%) and Klebsiella (2\%). Prospective study reveal ed timerel ated changes in organism isolation. Gram positive organisms were initially prevalent then were gradually superceded by Gram negative organisms (Table- II). Mixed organisms were absent on admission culture which were gradually increasing up to Day 21 . I solation of Staphylococcus aureus was $42 \%$ on admission and was gradually decreasing to $4 \%$ on Day 21 . On the other hand single isolation of Pseudomonas aeruginosa and Esch. coli were $6 \%$ each on admission culture which were gradually increasing upto $40 \%$ and $28 \%$ respectively on Day 21 . The antibiogram of Gram negative organisms isolated from burn wound is shown in Table III. Pseudomonas aeruginosa was highly sensitive to Imipenem $(98.72 \%)$ followed by Aztreonams (33.44\%) and Ceftazidime (28.32\%) but resistance to Ampicillin and Tetracycline was $100 \%$ followed by Cotrimoxazole (97.28\%), Cephal exin (94.72\%), Ciprofloxacin (92.16\%), Ceftriaxone (84.48\%) and Gentamycine $(80.77 \%)$. Similarly Esch. coli was highly sensitive to imepenem (98.15\%). Its resistance to Ampicillin was $88.8 \%$ followed by Tetracycline $(85.1 \%)$, Cephalexin (79.55\%), Cotrimoxazole (75.85\%), Ciprofloxacin (64.75\%), Chloramphenicol (62.9\%) and Gentamicin (61.05\%).Klebsiella, Proteus, Enterobacter and Acinetobacter was $100 \%$ Sensitive to Imipenem. Antimicrobial Sensitivity Pattern of Gram positive organisms isolated from burn wound is shown in Table IV. Staphylococcus aureus were $100 \%$ resistant to penicillin and conversely $100 \%$ sensitive to vancomycin followed by Oxacillin and Amoxiclav ( $53.47 \%$ each), Ceftriaxone (46.5\%), Gentamicin (44.7\%), Cloxacillin (39.52\%), Cephal exin (37.2\%), Ciprofloxacin (34.88\%), Tetracycline (30.22\%), Cotrimoxazole $(20.92 \%)$ and Ampicillin (9.3\%).

Table I. Organisms isolated from 200 samples (50 bum patients)

\begin{tabular}{lccc}
\hline \multirow{2}{*}{ Organisms } & \multicolumn{2}{c}{ Number of isolation } & T otal \\
\cline { 2 - 3 } & Single & M ixed & \\
\hline Pseudomonas aeruginosa & $56(28)$ & $22(11)$ & $78(39)$ \\
Esch. coli & $35(17.5)$ & $19(9.5)$ & $54(27)$ \\
Staph. aureus & $32(16)$ & $11(5.5)$ & $43(21.5)$ \\
Coagulase-veStaphylococcus & $9(4.5)$ & - & $9(4.5)$ \\
Klebsiella & $4(2)$ & $1(0.5)$ & $5(2.5)$ \\
Proteas & $2(1)$ & $2(1)$ & $4(2)$ \\
Q-haemblytic Streptococcus & $2(1)$ & - & $2(1)$ \\
Enterobacter & $1(0.5)$ & - & $1(0.5)$ \\
Acinetobacter & $1(0.5)$ & - & $1(0.5)$ \\
No growth & $31(15.5)$ & - & $31(15.5)$ \\
Mixed & - & $27(13.5)$ & $27(13.5)$ \\
\hline
\end{tabular}


Table II. Timerelated changes in organismisolation from bum wound

\begin{tabular}{|c|c|c|c|c|c|c|c|c|c|c|}
\hline \multirow[t]{2}{*}{ Microorganisms } & \multicolumn{2}{|c|}{$\begin{array}{c}\mathbf{O n} \\
\text { admission } \\
n=50\end{array}$} & \multicolumn{2}{|c|}{$\begin{array}{c}7^{\text {th }} \text { day } \\
n=50\end{array}$} & \multicolumn{2}{|c|}{$\begin{array}{c}14^{\text {th }} \text { day } \\
n=50\end{array}$} & \multicolumn{2}{|c|}{$\begin{array}{c}21^{\text {st }} \text { day } \\
n=50\end{array}$} & \multicolumn{2}{|c|}{$\begin{array}{l}\text { Total } \\
n=200\end{array}$} \\
\hline & No. & $\%$ & No. & $\%$ & No. & $\%$ & No. & $\%$ & No. & $\%$ \\
\hline Pseudomonas & 3 & 6 & 15 & 30 & 18 & 36 & 20 & 40 & 56 & 28 \\
\hline Esch. Coli & 3 & 6 & 8 & 16 & 10 & 20 & 14 & 28 & 35 & 17.5 \\
\hline Staph. aureus & 21 & 42 & 6 & 12 & 3 & 6 & 2 & 4 & 32 & 16 \\
\hline CoNS & 8 & 16 & 1 & 2 & - & - & - & - & 9 & 4.5 \\
\hline Klebsiella & - & - & 1 & 2 & 1 & 2 & 2 & 4 & 4 & 2 \\
\hline Proteus & - & - & & & 1 & 2 & 1 & 2 & 2 & 1 \\
\hline$\alpha$-Haemolytic Streptococcus & 1 & 2 & 1 & 2 & & & & & 2 & 1 \\
\hline Enterobacter & - & - & - & - & 1 & 2 & - & - & 1 & 0.5 \\
\hline Acinetobacter & - & - & - & - & - & - & 1 & 2 & 1 & 0.5 \\
\hline No growth & 14 & 28 & 10 & 20 & 7 & 14 & 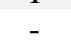 & & 31 & 15.5 \\
\hline Mixed Organisms & - & - & 8 & 16 & 9 & 18 & 10 & 20 & 27 & 13.5 \\
\hline
\end{tabular}

Table III. Antimicrobial sensitivity pattern of Gram negative organisms isolated from bum wound

\begin{tabular}{|c|c|c|c|c|c|c|c|c|c|c|c|c|c|}
\hline \multirow{2}{*}{$\begin{array}{l}\text { Antim } \\
\text { icrobi } \\
\text { d } \\
\text { agent }\end{array}$} & \multirow[t]{2}{*}{$\begin{array}{l}\text { Sensiti } \\
\text { vity }\end{array}$} & \multicolumn{2}{|c|}{$\begin{array}{c}\text { Pseudomonas } \\
\text { Aeruginosa } \\
n=78\end{array}$} & \multicolumn{2}{|c|}{$\begin{array}{c}\text { Esch.coli } \\
n=54\end{array}$} & \multicolumn{2}{|c|}{$\begin{array}{c}\text { Klebsiella } \\
n=5\end{array}$} & \multicolumn{2}{|c|}{$\begin{array}{c}\text { Proteus } \\
n=4\end{array}$} & \multicolumn{2}{|c|}{$\begin{array}{c}\text { Enterobacter } \\
\quad n=1\end{array}$} & \multicolumn{2}{|c|}{$\begin{array}{c}\text { Acientobacter } \\
n=1\end{array}$} \\
\hline & & No. & $\%$ & No. & $\%$ & No. & $\%$ & No. & $\%$ & No. & $\%$ & No. & $\%$ \\
\hline \multirow[t]{2}{*}{ AMP } & $\mathrm{S}$ & 0 & 0 & 6 & 11.2 & 0 & 00 & 0 & 00 & 0 & 00 & 0 & 00 \\
\hline & $\mathrm{R}$ & 78 & 100 & 48 & 88.8 & 5 & 100 & 4 & 100 & 1 & 100 & 1 & 100 \\
\hline \multirow[t]{2}{*}{$\mathrm{CN}$} & S & 15 & 19.23 & 21 & 38.95 & 2 & 40 & 1 & 25 & 1 & 100 & 0 & 00 \\
\hline & $\mathrm{R}$ & 63 & 80.77 & 33 & 61.05 & 3 & 60 & 3 & 75 & 0 & 0 & 1 & 100 \\
\hline \multirow[t]{2}{*}{ CRO } & S & 12 & 15.52 & 16 & 29.7 & 3 & 60 & 2 & 50 & 00 & 0 & 00 & \\
\hline & $R$ & 66 & 84.48 & 38 & 70.3 & 2 & 40 & 2 & 50 & 1 & 100 & 1 & 100 \\
\hline \multirow[t]{2}{*}{ CIP } & $S$ & 6 & 7.84 & 19 & 35.25 & 2 & 40 & 2 & 50 & 0 & 00 & 0 & 00 \\
\hline & $\mathrm{R}$ & 72 & 92.16 & 35 & 64.75 & 3 & 60 & 2 & 50 & 1 & 100 & 1 & 100 \\
\hline \multirow[t]{2}{*}{$\mathrm{CL}$} & $S$ & 4 & 5.28 & 11 & 20.45 & 1 & 20 & 1 & 25 & 0 & 00 & 0 & 00 \\
\hline & $\mathrm{R}$ & 74 & 94.72 & 43 & 79.55 & 4 & 80 & 3 & 75 & 100 & 1 & 100 & \\
\hline \multirow[t]{2}{*}{$\mathrm{T}$} & $S$ & 0 & 00 & 8 & 14.9 & 1 & 20 & 0 & 0 & 00 & 0 & 0 & 00 \\
\hline & $\mathrm{R}$ & 78 & 100 & 46 & 85.1 & 4 & 80 & 4 & 100 & 1 & 100 & 1 & 100 \\
\hline \multirow[t]{2}{*}{ SXT } & $S$ & 2 & 2.77 & 13 & 24.15 & 0 & 00 & 0 & 00 & 0 & 00 & 0 & 00 \\
\hline & $\mathrm{R}$ & 76 & 97.28 & 41 & 75.85 & 5 & 100 & 4 & 100 & 1 & 100 & 1 & 100 \\
\hline \multirow[t]{2}{*}{ IPM } & $S$ & 77 & 98.72 & 53 & 98.15 & 5 & 100 & 4 & 100 & 1 & 100 & 1 & 100 \\
\hline & $\mathrm{R}$ & 1 & 1.28 & 1 & 1.85 & 0 & 00 & 0 & 00 & 0 & 00 & 0 & 00 \\
\hline \multirow[t]{2}{*}{ CAZ } & $S$ & 22 & 28.32 & & & & & & & & & & \\
\hline & $\mathrm{R}$ & 56 & 71.68 & & & & & & & & & & \\
\hline \multirow[t]{2}{*}{ ATM } & $S$ & 26 & 33.44 & & & & & & & & & & \\
\hline & $\mathrm{R}$ & 52 & 66.56 & & & & & & & & & & \\
\hline \multirow[t]{2}{*}{ C } & $S$ & & & 20 & 37.1 & & & & & & & & \\
\hline & $\mathrm{R}$ & & & 34. & 62.9 & & & & & & & & \\
\hline
\end{tabular}


Table IV. Antimicrobial sensitivity pattern of Gram positive organisms isolated from bum wound

\begin{tabular}{|c|c|c|c|c|c|}
\hline \multirow[t]{2}{*}{$\begin{array}{l}\text { Antimicrobial } \\
\text { agent }\end{array}$} & \multirow[t]{2}{*}{ Sensitivity } & \multicolumn{2}{|c|}{$\begin{array}{l}\text { Staphylococcus } \\
\text { aureus } n=43\end{array}$} & \multicolumn{2}{|c|}{$\begin{array}{c}\text { CoNS } \\
\mathrm{N}=9\end{array}$} \\
\hline & & No. & $\%$ & No. & $\%$ \\
\hline $\mathrm{P}$ & $\begin{array}{l}\mathrm{S} \\
\mathrm{R}\end{array}$ & $\begin{array}{r}0 \\
43\end{array}$ & $\begin{array}{r}00 \\
100\end{array}$ & $\begin{array}{l}0 \\
9\end{array}$ & $\begin{array}{r}00 \\
100\end{array}$ \\
\hline AMP & $\begin{array}{l}\mathrm{S} \\
\mathrm{R}\end{array}$ & $\begin{array}{r}4 \\
39\end{array}$ & $\begin{array}{r}9.3 \\
90.73\end{array}$ & $\begin{array}{l}1 \\
8\end{array}$ & $\begin{array}{l}11.12 \\
88.88\end{array}$ \\
\hline CRO & $\begin{array}{l}S \\
R\end{array}$ & $\begin{array}{l}20 \\
23\end{array}$ & $\begin{array}{l}46.5 \\
53.5\end{array}$ & $\begin{array}{l}5 \\
4\end{array}$ & $\begin{array}{l}55.55 \\
44.44\end{array}$ \\
\hline $\mathrm{CL}$ & $\begin{array}{l}S \\
R\end{array}$ & $\begin{array}{l}16 \\
27\end{array}$ & $\begin{array}{l}37.2 \\
62.8\end{array}$ & $\begin{array}{l}5 \\
4\end{array}$ & $\begin{array}{l}55.55 \\
44.44\end{array}$ \\
\hline $\mathrm{CIP}$ & $\begin{array}{l}S \\
R\end{array}$ & $\begin{array}{l}15 \\
28\end{array}$ & $\begin{array}{l}34.88 \\
65.12\end{array}$ & $\begin{array}{l}4 \\
5\end{array}$ & $\begin{array}{l}44.44 \\
55.55\end{array}$ \\
\hline OB & $\begin{array}{l}S \\
R\end{array}$ & $\begin{array}{l}17 \\
26\end{array}$ & $\begin{array}{l}39.52 \\
79.48\end{array}$ & $\begin{array}{l}3 \\
6\end{array}$ & $\begin{array}{l}33.33 \\
66.66\end{array}$ \\
\hline SXT & $\begin{array}{l}S \\
R\end{array}$ & $\begin{array}{r}9 \\
34\end{array}$ & $\begin{array}{l}20.92 \\
79.08\end{array}$ & $\begin{array}{l}2 \\
7\end{array}$ & $\begin{array}{l}22.22 \\
77.77\end{array}$ \\
\hline$E$ & $\begin{array}{l}S \\
R\end{array}$ & $\begin{array}{l}10 \\
33\end{array}$ & $\begin{array}{l}23.25 \\
76.75\end{array}$ & $\begin{array}{l}3 \\
6\end{array}$ & $\begin{array}{l}33.33 \\
66.66\end{array}$ \\
\hline $\mathrm{T}$ & $\begin{array}{l}\mathrm{S} \\
\mathrm{R}\end{array}$ & $\begin{array}{l}13 \\
30\end{array}$ & $\begin{array}{l}30.22 \\
69.78\end{array}$ & $\begin{array}{l}5 \\
4\end{array}$ & $\begin{array}{l}55.55 \\
44.44\end{array}$ \\
\hline $\mathrm{CN}$ & $\begin{array}{l}\mathrm{S} \\
\mathrm{R}\end{array}$ & $\begin{array}{l}20 \\
23\end{array}$ & $\begin{array}{l}44.7 \\
55.3\end{array}$ & $\begin{array}{l}6 \\
3\end{array}$ & $\begin{array}{l}66.66 \\
33.33\end{array}$ \\
\hline ox & $\begin{array}{l}\mathrm{S} \\
\mathrm{R}\end{array}$ & $\begin{array}{l}23 \\
20\end{array}$ & $\begin{array}{l}53.47 \\
46.53\end{array}$ & $\begin{array}{l}5 \\
4\end{array}$ & $\begin{array}{l}55.55 \\
44.44\end{array}$ \\
\hline VA & $\begin{array}{l}S \\
R\end{array}$ & $\begin{array}{l}43 \\
00\end{array}$ & $\begin{array}{r}100 \\
00\end{array}$ & $\begin{array}{l}9 \\
0\end{array}$ & $\begin{array}{r}100 \\
00\end{array}$ \\
\hline AMC & $\begin{array}{l}\mathrm{S} \\
\mathrm{R}\end{array}$ & $\begin{array}{l}23 \\
20 .\end{array}$ & $\begin{array}{l}53.47 \\
46.53\end{array}$ & $\begin{array}{l}5 \\
4\end{array}$ & $\begin{array}{l}55.55 \\
44.44\end{array}$ \\
\hline
\end{tabular}

$\mathrm{P}=$ Penicillin, $\mathrm{AMP}=$ Ampicillin, $\mathrm{CRO}=$ Ceftriaxone , $\mathrm{CL}=$ Cephalexin , $\mathrm{CIP}=$ Ciprofloxacin, $\mathrm{OB}=$ Cloxacillin , SXT = Cotrimoxazole, $\mathrm{E}=$ Erytromycin , $\mathrm{T}=$ Tetracycline, $\mathrm{CN}=$ Gentamicin, $\mathrm{OX}=$ Oxacillin , $\mathrm{VA}=$ Vancomycin, $\mathrm{AMC}=$ Amoxiclav .

\section{Discussion}

Infection is an important cause of morbidity and mortality in burns. Severe burn patients are very susceptible to infection because of wide exposed raw areas, the presence of necrotic tissue, protein rich exudates, inability of blood to reach the colonized areas of wounds and other host defense mechanisms. The colonization and later invasion of tissues is from patient's normal flora of skin or from gastrointestinal tract or more usually by cross infection ${ }^{7-10}$. In the face of high mortality because of bacteraemia in burned patients, it is important to select antibiotics or combination of antibiotics with broad coverage for the usual pathogens. In a large number of patients this has to be empirical pending results of cultures ${ }^{11}$. As the type of bacteria and their sensitivity vary from place to place analysis of bum wound microbial colonization is to be performed so that the prophylactic and therapeutic regimens could be rationalized. There are also time related changes in bum wound microbial colonization. Different types of study on burn wound infection have been carried out in different countries of the world.
Among them few were regarding timerelated changes in bacterial colonization. In Bangladesh timerelated changes in bum wound infection were not included in previous studies. Infection with one or more organisms was present in $84.5 \%$ cases in our study. Single organism was isolated in $71 \%$ and mixed organism in $13.5 \%$ and no growth in $15.5 \%$ swabs. Incidence of infection varies from place to place and country to country due to different therapeutic and preventive policy ${ }^{12}$.

Pseudomonas aeruginosa isolation was maximum in our study in both single (28\%) and mixed (11\%) infection (Table I). These findings were consistent with those of other centers of different countries, ${ }^{5,10,13}$. But in a previous study in our country isolation of Staphylococcus aureus was leading ${ }^{14}$. In our study Esch. coli was the second most common organism isolated singly $(17.5 \%)$ or in combination with other organisms followed by Staphylococcus, Klebsiella and others. Beta-haemolytic Streptococcus was not found in the wounds of any patient. Similarly the complete absence of B-haemolytic Streptococcus was also reported by some workers $1,10,13,15,16,17$. But some other workers found the organism in post bum infection ${ }^{3,5,18}$.

Analysing the results of four wound swabs taken from bum wound of each patient it was observed that by day 21 all the samples yielded growth, number of mixed growth was highest and Gram negative organisms were predominant. All these changes were gradual from the starting to the end of sample collection (Table II). On Day 0 colonization by Staphylococcus aureus was $42 \%$ followed by Pseudomonas aeruginosa $6 \%$ and Esch. coli $6 \%$. On Day 7 it was $12 \%, 30 \%$ and $16 \%$; on Day 14 the percentage was 6\%,36\% and $20 \%$; on Day 21 it was $4 \%, 40 \%$ and $28 \%$ respectively. On Day 0 there was no mixed growth which was $20 \%$ on Day 21 . All the $(100 \%)$ swabs yielded growth on Day 21 . Present study revealed that Gram positive cocci (Staphylococcus aureus) were initially prevalent then were gradually superceded by Gram negative bacilli specially Pseudomonas aeruginosa throughout patients hospital stay of 21 days. The study results of various worker revealed that the bacteriology of burn infection has been changing from time to time and also the antimicrobial sensitivity pattern. There are also time related changes in burn wound microbial colonization. Gram positive cocci are initially prevalent then are gradually superceded by Gram negative bacilli throughout the patients hospital stay $^{1,4,19,20}$ that have a greater propensity to invade ${ }^{21}$. These timerelated changes have also been found in our study (Table II). Periodic reviews of patterns of isolation and susceptibility profiles of organisms infecting burn wounds are needed in order to modify the preventive and therapeutic strategies ${ }^{13}$. It is therefore essential for every burn institution to determineits specific pattern of burn wound microbial 
colonization, timerelated changes in predominant flora and antimicrobial resistance profile. This would allow early management of septic episode with proper empirical systemic antibiotics before the results of microbiological cultures become available thus improving the overall infection related morbidity and mortality 5 .

\section{Conclusion and recommendation}

There were time-related changes in microbial colonization during hospital stay of patients. Initially Staphylococcus was predominant organism isolated from bum wound which was gradually superceded by Gram negative organism specially Pseudomonas aeruginosa.

For empirical treatment of wound infection in the first week when Staphylococcus aureus is predominant, Amoxyclav and from second week onward as Gram negative organism specially Pseudomonas aerugi nosa is predominant, Gentamicin may be applied which will be cost-effective. Vancomycin and I mepenem are costly as well as reserve drugs. For imminent septic episode in the first week, Vancomycin and in the second week onward Imepenam is recommended before culture and sensitivity report. Prompt energetic effort is needed for comprehensive care of the patient so that hospital stay can be shortened thereby improving overall infection related morbi dity and mortal ity.

\section{R eferences:}

1. Vindenes $H$, Bjerknes $R$. Microbial colonization of large wounds. Burns 1995;21:575-9.

2. Rahman A, Rahman AKMF, Shafniaz S, Llinnan M. Bangladesh Heal th and I njury Survey Report on Children 2005.

3. Neelam T, Rekha E, Chari PS, Meera S. A prospective study of hospital - acquired infections in burn patients at a tertiary care referral center in North India. Burns 2004;30:660-69.

4. Pruitt BA J r. The diagnosis and treatment of infection in the burn patient. Burns 1984;11:79.

5. Salah N, Amr M, Ashraf M. Colonization of burn wounds in Ain shams University Burn unit. Burns 2003;29:229-33.

6. UlkuA, Serpil E, Fehmi AMNC, Kadanali, Ayten. The time related changers of antimicrobial resistance patterns and predominant bacterial profiles of burn wounds and body flora of burned patients. Burns 2004;30:660-64.

7. Cheesbrough M. Medical Laboratory Manual for Tropical countries Vo. II. editor. ELBS, 2000.

8. NCCLS performance standards for Antimicrobial disc susceptibility Tests: Tentative standard, 4th ed. Villanova, P.A, USA, 1988.

9. Forbes BA, SahmDF, Weissfeld AS. Bailley and Scott's diagnostic microbiology. 10th ed. St. Louis (CV): Mosby,1998.
10. Husain MT. Karim QN, Tajuri S. Analysis of infection in a burn ward. Burns 1989;15( 5):299-302.

11. Wilkinson TJ, Brent JG. The selective use of systemic antibiotics in the treatment of burns. Surg. Gynecol. Obstet. 1981;151:404.

12. A ppelgren P, Bjornhagen V, Bragderdy K, J onsson CV, Ransto U. A prospective study of infections in burn patients. Burns 2002;28:39-46.

13. Singh NP, Goyal R, Manchanda V, Das S, Kaur I, Talwar V. Changing trends in bacteriology of burns in the burn unit, Delhi, India. Burns 2003;29:129-32.

14. Hasan MS. Studies on aetiology of infection of burn patients admitted in Dhaka Medical College Hospital. Thessis, University of Dhaka 1994.

15. Bharadwaj R, Phadke SA, J oshi BN. Bacteriology of burn wound using the quantitative full thickness biopsy technique Indian J. Med. Res. 1983;78:337-42.

16. Karyoute SM. Burn wound infection in 100 patients treated in the burn unit at J ordon University Hospital. Burns 1989;15(1):117-19.

17. Rahman MM, Gomes DJ, Chowdhury N, Hasan Z, Rahman SR, Huq F. Drug sensitivity pattern of aerobic bacteria isolated from infected wounds of 40 diabetic and 60 nondiabetic patients. Bangladesh Medical College J ournal 1997;2(1):20-5.

18. Gupta N, Haque A, Mukhopadhyay G, Narayan RP. Prasad R. Interactions between bacteria and cardida in the burn interactions between bacteria and candida in the burn wound. Burns 2005;31(3):375-78.

19. MacMillan BG. Infections following burn injury. Surg Clin North Am 1980;60:185-96.

20. Manson WL, Pernot PCJ, Filder V, Sauer EW, Kalsen HJ. Colnization of burns and the duration of hospital stay of severely burned patients, J ournal of hospital Infection 1992;22:55-63.

21. Pruitt BA Jr., McManus AT, KimSH, Goodwin CW. Burn wound infections: Current Status. WorldJ Surg. 1998;22:135-45. 